\author{
JeLENA Đ. Premović ${ }^{1}$ \\ INSTITUTE OF ECONOMY, BELGRADE \\ LJILJANA J. ARSIĆ ${ }^{2}$ \\ UNIVERSITY OF PRIŠTINA IN KOSOVSKA MITROVICA \\ FACULTY OF ECONOMY IN KOSOVSKA MITROVICA
}

\title{
SOCIO-ECONOMIC ASPECTS OF TOURISM IN THE MODERN SOCIETY
}

\begin{abstract}
The specificity of the tourist market and the connection of modern tourist products with numerous economic and non-economic activities cause the multiplicity of socio-economic effects of tourism. The development of tourism creates opportunities for a number of other activities, which means that tourism is a significant factor in boosting the overall economic development. Tourism plays a particularly important role in the overall socio-economic development of underdeveloped countries and regions. Tourism can contribute to positive socio-economic development, but at the same time, inadequate and uncontrolled management of a tourist destination can have negative socio-cultural, but also economic consequences.
\end{abstract}

The paper investigates the basic socio-cultural and economic aspects and impacts of tourism. The authors pay special attention to the analysis of the multiplying effects of tourism on the development of a particular destination. Starting from the history of travel and tourism as an activity, key motives and socio-economic effects, the 2008 World Economic Crisis, its origin, causes, and consequences of its impact on the entire world economy, especially tourism, the authors analyzed the current economic indicators of tourism activity in the world economy and projections of expected trends. In this paper, the focus of the analysis is on the tourist travel and economic and

\footnotetext{
jelena.premovic@gmail.com
}

ljiljana.arsic@pr.ac.rs

This paper was submitted on August $8^{\text {th }}, 2020$ and accepted for publication at the meeting of the Editorial Board held on September $25^{\text {th }}, 2020$. 
socio-cultural impact of tourism on the tourist destination, the individual, and the society as a whole.

KEYWORDS: travel; tourism; needs; motivation; socio-economic influence.

\section{INTRODUCTORY REMARKS}

Tourism is a social phenomenon and activity immanent to human nature, which has existed in various forms since the beginning of human society. Tourism has gradually become one of the most important indicators of economic and general social development-from ancient times, the slave-owning and feudal social system when the very beginnings of movement, through the period of the so-called 'oligo tourism' during the XIX century to World War II, the period until 1950, then through the so-called 'poly tourism' which covers the period from 1950 to 2000, all the way to modern and postmodern tourism today.

At the beginning of the new millennium, various processes are taking place in the world that directly and indirectly affect the physiognomy of tourism. After the production era and economies of scale, the entire world economy finds itself in the era of services, since the service sector participates with about 55\% in the total world economy, in comparison to the manufacturing-industrial sector with a share of $45 \%$. On average, about $65 \%$ of the income of developed countries comes from service activities, while modern trends expressed through the growing importance and representation of services support the assumptions that services will be represented in the global world economy in about 30 years with as much as $85 \%$ (Premović, Arsić, Vujović, 2012, p. 582).

In the total world trade in services, tourism participates with about $30 \%$ and is considered the service sector with the greatest growth potential expected in the coming period. Modern consumer society influences changes in the behavior and desires of modern tourists who demand high quality and sophisticated service. Growing perceptions andpreferences of tourists, who demand high quality tourist product and service, affect the staff employed in the tourism sector, who actively participate in creating the tourist offer and services, to constantly improve their knowledge and skills, not only because of the growing competition in the tourist market, but also to find new tourist facilities and services that will 
satisfy the desires and needs of modern tourists for new experiences (Premović, 2016, pp. 633-634).

In 2018, the tourism sector achieved record results with the number of tourist arrivals of 1.401 billion, which is 72 million more than in 2017. The share of tourism in the gross domestic product of the world in 2018 was about $10 \%$, while through tourism; over $7 \%$ of the value of total exports in the world was realized. These results have contributed to the tourism industry, in terms of export revenues in 2018 in the total amount of 1,700 billion dollars, taking the third place, right after the chemical and oil industry, achieving a total growth of $4 \%$.

\section{RESEARCH METHODOLOGY}

Tourism is a complex social activity influenced by many factors and principles. First of all, these are: economic, geographical, ecological, ethnic and sociological, cultural and safety factors. The specificity of the tourism market and the connection of modern tourism products with numerous economic and non-economic industries results in multiple socio-economic effects of tourism. Tourism development creates possibilities for initiating a number of other industries, which means that tourism represents a significant factor for initiating overall economic development. Tourism has a particularly important role (and should have!) in the overall socio-economic development of underdeveloped countries and regions (Premović, Arsić, 2018, pp. 92-106).

One of the specifics of tourism as economic industry or a model of economic development is to enable import at home (anything that tourists find interesting); where the products and services are prepared, there they are sold. Tourists (the demanders) come to the service providers or product vendors. If the specific destination, zone or region possesses quality inorganic, organic and anthropogenic elements, tourism is definitely an industry that provides economic development and inclusion in the international division of labor (Vujović, Macura, Spajić, 2011, p. 42). The positive effects of improving tourism industry can be seen at the micro level - at the level of a specific tourist destination, but also at the level of the national economy.

The mechanisms of the market, ie supply and demand enable the realization of the specifics of the development aspects of tourism, 
where the relationship between goods and needs indicates that all human efforts are directed towards the harmonization of needs and possibilities. Only when an individual has free time and free money he can think about traveling and vacationing outside his permanent place of residence (skiing, rafting, swimming, spa treatments, etc.). In the economy, it is generally accepted that free time and excess funds are two key preconditions for the development of tourism. So, economic development is a precondition for any tourism development.

Tourism demands are manifested through tourist consumption and are quantified by the amount of spent-bought relation. The dominance of commercial motives on the supply side gives the advantage to the economic approach and economic interests. Precisely, by realization and manifestation in a tourist place or destination, developmental and other aspects of tourism come to the fore. With the growing interest in getting to know different areas, cultures and local communities, tourism is finally becoming recognized as an activity that can develop these areas, create jobs for the local population and help preserve local culture and customs. This means that tourism offers not only the improvement of life to those who provide services, but also to those who use those services. Therefore, it is extremely important, as Professor Slavoljub Vujović warns, that all those who participate in the creation of tourism maintain an optimal balance in order to be able to check the sustainability of development (Vujović et al., 2011).

If viewed through the historical prism of development as industry, it is possible to note that tourism "experienced a number of highly significant (internal or external) transformations in its development: it received different forms, used various means, expanded its form in spatial and quantitative aspect, changed its features and structure, enriched itself with new motives, gained new functions, influenced differently and used different goals and, by doing so, never lost its economic characteristic" (Gligorijević, Stefanović, 2012, p. 271).

Guided by these facts, the paper investigates the basic economic and socio-cultural aspects and impacts of tourism. The authors pay special attention to the analysis of the multiplying effects of tourism on the development of a particular destination. Starting from the history of travel and tourism as an activity, key motives and socio-economic effects, the 2008 World Economic Crisis, its origin, causes and consequences of its impact on the entire world econo- 
my, especially tourism, the authors analyzed the current economic indicators of tourism activity in the world economy and projections of expected trends.

In addition to travel motivated by various tourist motives and needs, there are other kinds of travel that occur as a result of other human needs and motives and within economic and noneconomic activities. The focus of the analysis is on the tourist travel and economic and socio-cultural impacts of tourism on the tourist destination, the individual, and the society as a whole. The main goal of the paper is to point out the basic socio-cultural and economic aspects and impacts of tourism activity.

\section{SOCIO-CULTURAL EFFECTS OF TOURISM}

Free time as a prerequisite for tourist travel. The process of globalization and the domination of world capital lead to new redistributions of tourist income, new redistribution of tourist movements and rapid growth of new tourist regions. Under the influence of intensive technological development and globalization, the pronounced complexity and dynamism of the tourist market initiated changes in the structure of tourist supply and demand. The complexity of the tourist activity fuels the constant need to take new actions in order to adapt the tourist product to the requirements of the tourist demand by recognizing the needs of tourists, their realization, and appearance on the tourist market (Vujović, Cvijanović, Štetić, 2012, p. 9).

There are therefore two key preconditions for the development of tourism: free time and free funds that are allocated for that purpose. People started traveling as tourists only when they had free time. In different social epochs since ancient times, there have been different definitions and interpretations of free time. The opinion of Plato is impressive; he believed that in free time a person performed the most sublime activity, their own self-improvement. Socrates emphasized the importance of free time for doing good, humanistic, and sublime deeds.

Analyzing the causality of the relationship between free time and tourism as an activity, Professor Ratko Božović (Božović, 2009, p. 53) expresses the opinion that tourism represents, in a certain way, organized free time that is to some extent liberating, although it may have a certain dose of 'overstrain'. It is, in a way, 'a healing 
time' and can therefore be considered as a form of 'free time'. However, as he points out, "one should keep in mind the fact that the free time that is characteristic of tourism, can also be empty time. When it comes to tourism and free time, then we should not exclude the understanding of an ordinary citizen who is inclined to interpret tourism as a self-activity and even an activity that takes place in free time". No matter what type of tourism it is, tourism for tourists is "one of the best (most useful) free time spent", concludes the author.

Following the genesis of the development of tourism and free time used for vacation and various types of travel from the perspective of the present time, it is possible to see that, in contrast to free time used in the past for vacations and trips that lasted 15 days, in recent times, the use of several shorter trips lasting several days each (extended weekend, weekend travel-vacation, religious and public holidays, etc.) is increasingly present.

A journey through different civilizations, epochs, and cultures. Tourism is inextricably linked to travel and it is safe to say that without a certain form of travel there is no tourism. On the other hand, various forms of movement of people have existed since the emergence of human civilization, independently and without tourism. However, "different types of movement of people are equated by many authors with tourist movements, which are completely wrong. In order to know the moment of the appearance of tourism and all the greatness and significance of this activity, we need to take this into account." (Vujović, Cvijanović, Štetić, 2012, p. 10).

As Encensberger reminds us people have always been driven to travel by necessity, biological or economic necessity. The war expeditions of the ancient peoples were never stimulated by the desire to travel. The first people who, by their own logic, went to a distant world were merchants.

Although there is no one universal and generally accepted definition, tourism means any travel outside the permanent place of residence that lasts longer than 24 hours, pro vided that it is not for employment, economic reasons or change residence. As a term, tourism appeared at the beginning of the 19th century, which indicates a substantial deviation from the previous meaning of the term travel. The forerunner of the modern organization of tourist travel is Thomas Cook in England, who founded the first travel agency called 'Cook and Son' in 1841. 
Travel, as a manifestation of various human needs and motives, exists from the beginning of human society, from mythical antiquities and nomadic conquests of new spaces to the present day and the mass tourist travel we are witnessing. At the same time, throughout the long history of human existence, the motives and needs for travel have changed under the influence of different cultures and epochs and in parallel with the development of human society and a man as an individual. "Traveling today," says Boselman "is so often seen as 'fun' that the origin of the word travel is almost completely forgotten. It comes from the same root as the word work (travail) and, for most of history, travel has been thought of as hard work, as the old Arabic proverb says that there are three forms of curse: sickness, fasting and travel" (Vujović et al., 2012, p. 10).

Travel for pleasure dates back to the ancient times. The first travels in ancient Greece were for fun and entertainment, but also motivated by religious needs, which were the main motives of the Romans' travels. The period of the Middle Ages, marked as the 'dark age', also represented the dark age for travel. In the entire epoch of the old century, organized travels were not recorded until the 12th century, when the travels of nobles, preachers, and adventurers, who re-used carriages as a means of transportation, were recorded. The first mass travels were encouraged by the church by organizing various pilgrimages of believers and visits to sanctuaries. The period of Humanism and Renaissance is a period of flourishing cultural and spiritual creativity and travel. The desire to get to know new places, cultures, and gain new experiences prompted the then intellectual elite to travel throughout Europe, primarily to European capitals and economic and cultural centers. During the 18th and 19th centuries, numerous intellectuals and artists from various fields traveled intensively, and many of them, inspired by their travels, created various literary, painting, musical and other works as a kind of testimony to personal impressions from realized travels.

From the middle of the 16th to the middle of the 19th century, the circle of people and social strata that traveled expanded, so that representatives of the richer strata of the society at that time also traveled in greater numbers: nobility, aristocracy, and rich merchants. The motives for their travels, known as the "Grand Tour of Europe' were education and professional development and lasted from two to four years. In this period, a new class appears, the 
so-called 'traveling class. This period from the emergence of human society until the middle of the XIX century is referred to as the pre-tourist era, which is the precursor of the tourist era in which we live today.

The period of the tourist epoch from the middle of the 19th century to the present day is primarily determined by the mass travel, elasticity of tourist demand, increase in the number of foreign tourists, and foreign exchange inflow in the world, thus increasing the interdependence of tourism and natural environment. The end of World War II, the renewal and strengthening of world economy and national economies, the increase of wages and leisure funds, but also the development of education and cultural identity of the population have had the greatest impact on these phenomena. Also, the current tourist epoch is characterized by pronounced demands for nature conservation. The importance of nature and the environment for the development-but also the survival of the tourist activity and for ensuring the sustainable development of tourism and the entire human society-is especially emphasized.

\section{TOURIST MOTIVATION}

The main reason why individuals decide to travel for tourism is in their internal needs and different ways of satisfying them, since most of these needs cannot be met in the place of residence, i.e. 'at home'. Human needs can be observed and interpreted from the perspective of various scientific disciplines and activities, from psychology and medicine, through anthropology, sociology and economics, to traffic, construction, agriculture and many others. There are many different views on the topic of human needs, and consequently there are numerous theories on motivation. Motive is an inner strength or force that moves, stimulates and inspires each individual to meet needs or achieve certain goals, while motivation is a complex psychological process of encouraging and directing an individual to act in a certain way to achieve their needs and achieve goals and the desired state.

One of the most commonly cited theory of motivation is defined by Maslow. He categorized all the different human needs into a known hierarchical structure of needs that encompasses five basic levels of human needs. The hierarchical structure of needs means that an individual strives to satisfy the most important needs first, 
and when they achieve them, they strive to fulfill all other needs according to the degree of importance, i.e. according to their hierarchy. These are physiological needs, the need for security, love, belonging and attachment, the need for respect, and the need for personal development and new experience (self-affirmation, self-actualization or self-realization).

Bearing in mind that the subject of the study is tourist travel that arises as a consequence of meeting tourist needs and motives, we will not engage in a more detailed critical analysis of human needs and various theories of motivation, but will start from a general division of needs into primary (existential) and secondary human needs that follow the satisfaction of the primary ones. The focus of research is therefore tourism needs that belong to the group of secondary human needs. Similarly, tourist motivation is "a collective expression of everything done towards certain goals, which give an individual a reason, motivation to partake various tourist activities" (Jandrešić, 2001, p. 123).

The need for rest, sports, and recreation can be met through tourist travel and it belongs to the tourist needs, the needs of self-affirmation. The needs of self-realization or self-affirmation can be met by visiting various cultural contents and cultural events. Only when all primary (existential) needs are met, it is possible to realize tourist needs as needs of a higher order, that is, secondary needs.

In order to organize a tourist travel and all the relations that arise in the tourist market between the offer and the demand, an individual should decide on a destination. In order to make such a decision and plan the travel, an individual needs to recognize the need beforehand and be motivated to satisfy that need. Although there are those authors who think the exact opposite, emphasizing that spontaneity, unplannedness, unexpectedness and the factor of surprise are key elements of any quality travel. This stream of thought also includes the position of John Steinbeck, according to whom "people do not go on a journey. The journey goes to them". Therefore, it should not be specially planned and analyzed, but simply enjoyed.

The motivation has a decisive influence on the decision to travel and the purchase of a specific tourist offer. Čomić points out that "tourist motivation is created under the influence of needs and other internal incentives, which act from within, and spatial stimuli, which are determined from the outside. They encourage a per- 
son to be active in a certain direction, that is, the individual strives to get closer to the object of his desires, a specific tourist facility" (Чомић, 1990, p. 16).

When it comes to motivation for tourist travel, they are, as has been said, numerous and different and have changed over time under the influence of numerous factors and circumstances. Professor Svetislav Milenković points out the dominant influence of modern socio-economic trends in the world on tourism and the behavior of tourist travelers. As the professor explains, "the structure of travelers changes the structure of tourist motives, so that new forms of tourism appear, especially related to the offer of high quality products, tourism in protected areas of the world, which at the same time means that tourist movements change character, on the one hand elitism, on the other side of extremism" (Milenković, 2009, p. 18).

"The causes of tourist travel should be sought primarily in the needs and different ways of satisfying those needs, that is, in the impossibility to satisfy certain needs at home or to be satisfied in a certain way. It can be any need, but a certain number of needs that people most often satisfy through tourist travel are realistically differentiated" (Чомић, 1990, р. 16).

Slobodan Vukićević views tourist travel as an expression of pleasure and fun: "A tourist travels to cross the boundaries of the space in which he constantly lives, to get out of the said space, but also out of himself as he is in that space. Therefore, tourism is a form of exercising freedom" (Вукићевић, 2007, p. 48).

Regardless of the different approaches in the interpretation of key tourist needs and motives, there is an almost unique view that the factors influencing their creation can be objective and subjective in nature. Objective factors include socio-economic and cultural factors such as ocial structure of the population, level of education, occupation, quality of the environment and the like. Subjective factors are internal psychological processes: specific needs, interests, desires and emotions, which can inspire an individual to travel. Motives and needs therefore encourage individuals to travel as tourists to a destination outside their place of permanent residence.

However, despite the individual approach to travel in relation to personal needs, opportunities, affinities and expectations that decisively influence the causes of tourist travel, it can be noted that the most common reasons are: the need for rest and relaxation, 
escape from everyday life, the need for health, wellness, fitness, sports and adventures, religious reasons and religious needs, the need for art, sightseeing and round trips, the need to meet new people, attend seminars, conferences and exhibitions, business reasons, visit friends and relatives, shopping and others.

The increase in the degree of education of the population, excess of free time and free funds have over time predominantly influenced the change in the hierarchy of needs of the vast majority of the world's population, so that today there is a growing opinion that tourist needs should be treated as basic human needs, not as a luxury reserved only for the social and economic elite. This was significantly influenced by the increasingly accessible tourist products and the development of tourism in the underdeveloped regions. The authors of this paper agree with these views.

According to Professor Stevo Nikić (2012, p. 30) culture represents the very essence and the base of tourist behavior, and this is again part of the general culture and is defined as the totality of tourist habits in terms of the culture of travel, rest and business. It also depends on the basic cultural assumptions that someone in Paris will visit the Louvre and someone will visit Disneyland, in Barcelona, it will be the famous cathedral or stadium of a football club, in Moscow it is the Bolshoi Theater or the Moscow Circus, someone will listen to serious music while someone will prefer techno music.

In tourist destinations and countries that have developed tourism, significant sociocultural influences and effects of tourism can be observed. Namely, the development of tourism increases the general level of education and culture of the local population that provides tourist services. Tourism provides an opportunity to travel and get to know other places, continents, nations, religions, cultures, traditions, languages. With the development of tourism, it is possible to establish stronger ties and relations between nations, creating and constantly developing awareness of the essential richness of diversity and respect for different cultures, religions, nations and lifestyles. There is a growing interest in various forms of culture and research of tradition, in learning foreign languages, information and communication technologies and monitoring the demands of tourists.

It can be said that "in addition to liberation from the numerous restrictions imposed by everyday life in the place of residence, tourism is also the pursuit of positive freedom, which will allow 
each individual to achieve their specific essence through travel, that is to design a journey in accordance with certain values and ideals that the individual perceives as an authentic need, not as something imposed from outside" (Чомић, 1990, str. 16).

The one who does not travel is no $\mathrm{man}^{3}$

Petar II Petrović Njegoš

When we talk about tourism as a social phenomenon par excellence and socio-cultural aspect of its impact, we consider it appropriate to highlight certain attitudes and quotes on tourist travel of some important thinkers, writers, statesmen and other famous individuals who marked the time in which they lived. As mentioned previously, travel has been considered since the ancient times. From that period, different opinions were recorded on the topic of travel, of which we selected the following:

- He who does not travel does not know the value of a man. (Moorish proverb)

- The world is a book, and those who do not travel, read only one page. (Saint Augustine)

- Travel brings strength and love back to your life. (Rumi)

- Traveling and changing places give the mind new strength. (Seneca)

Rilke pointed out that travel influenced the formation of personality and that travel had the deepest influence on his education, artistic work and formation as a poet. Speaking about the essence of tourism, Rilke says that its purpose is to develop one's ability to bring oneself into a state of listening and openness to the truth and careful observation. He warned that we must not travel lightly, because an unprepared trip was essentially a delusion, which was why he was preparing for certain travels for years (In: Божовић, 2009).

Numerous authors have written about the importance of travel for the development of knowledge and personality. The following views are some of them:

- Don't tell me how educated you are, tell me how far you've traveled. (Muhammad, the Islamic Prophet)

- To travel means to develop. (Pierre Bernardo)

3 “Није човјек ко не путује.” Петар II Петровић Његош 
- For young people, travel is a part of education, for old people it is a part of experience. (Francis Bacon)

Hesse spoke of travel as a kind of poetry that was reflected "in experience, which means in enrichment, in the organic reception of the newly acquired, in increasing our understanding of unity in diversity, the great weaving of earth and humanity, in rediscovering old truths and laws under completely new circumstances" (H. Hesse).

Meša Selimović also wrote in detail about travel and its positive psychological and social impact. We quote the following views of our famous writer: "Everyone should be forced to travel, from time to time. Furthermore, to never stop anywhere longer than necessary. Man is not a tree, and being bonded in one place is his misfortune, it takes away his courage, it diminishes his security. By bonding himself to one place, a man accepts all conditions, even unfavorable ones, and frightens himself with the uncertainty that awaits him. The change feels like abandonment, a loss of investment-someone else will occupy his conquered space so he will have to start all over again. Complacence is the real beginning of growing old, because a person is as young as they are not afraid to start again. By staying, a person suffers or attacks. By leaving, he keeps his freedom; he is ready to change the place and the imposed conditions" (Meša Selimović).

Tourism influences the development of creativity and the spread of cognitive, educational and cultural aspects.

- Every travel has some advantage. If a traveler visits a better, richer country, he can learn how to improve his own. And if he goes to the poorer country, he will learn how to enjoy his country. (Samuel Johnson)

- Please be a traveler, not a tourist. Try new things, meet new people, and look at what is in front of you. These are the keys to understanding the world we live in. (Andrew Zimern)

- Our destination is never a place, but a new way of looking at things. (Henri Miller)

- In twenty years, you will be more disappointed with the things you didn't do than the things you did. Sail, therefore, from a safe harbor. Discover, dream, explore! (Mark Twain)

- Travel is the re-establishment of the original harmony that once existed between the man and the universe. (Antol Frans) 
- We travel because distance and diversity are the secret fresheners of creativity. When we get home, the house is still the same. But something inside our mind has changed, and it changes everything. (Johan Lehrer)

- Travel is a form of free time that frees a person the most because he leaves the environment in which he lives every day; travel is a double freedom, one does not work and is not at home. (Jost Kripendorf)

We can also look at tourism as a specific game. Namely, as Professor Ratko Božović vividly described it: "A tourist is a player. Not because the game is an accompanying phenomenon designed to attract tourists, but because the tourists spontaneously take part in the game, thus becoming a kind of homo ludens" (Božović, 2009, p. 52).

\section{MUTIPLYING EFFECTS OF TOURISM}

The economic and financial aspects of tourism are numerous and obvious, as evidenced by the accessible data on tourism activities at the micro, macro and global levels. When it comes to the global results of tourism in the world, the share of tourism in the gross domestic product of the world is about $10.5 \%$, over $12.5 \%$ of the value of total exports in the world and about $30 \%$ of world trade in services. In 2017, a record growth in the number of tourists of as much as $7 \%$ was achieved compared to 2016 , and in 2018 , a further growth of $4 \%$ compared to 2017 continued.

Tourism has significant potential as the initiator of economic recovery and the strengthening of national economies. Tourism has a particularly significant role in the overcoming of the economic and financial crisis from 2008 which is why it is becoming a more successful model of economic growth and development.

The dynamism, heterogeneity and multifunctional use of the products of national economy in tourism are increasingly connecting tourism with the general socio-economic system. It is no longer just an ordinary subsystem of a large economic system, but it is an active participant in changing the structure and functioning of that system. Since they are aggregates, which determine a large economic system in cause-and-consequence relations, it makes tourism to act directly and indirectly to establishment of optimal 
cross-sector relations and multiplicative connections to economic development (Milenković, 2009, p. 75). Considering the fact that tourism is a dynamic and active economic category, the relations between tourism and other economic and non-economic industries should be considered in their dynamism and temporal perspective. In this context, it is important to determine the value of the multiplication coefficient which shows the number of turnover of income from foreign tourists during one year. In 1961, Clement first estimated the value of the tourism multiplier based on the following formula:

$$
\begin{gathered}
\mathrm{K}=1 / 1-\Delta \mathrm{C}: \Delta \mathrm{Y} \\
\mathrm{K}-\text { multiplication coefficient } \\
\Delta \mathrm{C} \text { - change in consumption } \\
\Delta \mathrm{Y} \text { - change in income }
\end{gathered}
$$

Applying this formula, Clement came to the conclusion that \$1 of direct tourism consumption in its turnover through indirect tourism consumption, ie by increasing the income of other industries and activities that make up the tourism product, increases that income by 2.48 times (3.48-1). The multiplication coefficient directly depends on the level of economic development of the domestic economy, that is, on the size of imports to meet the needs of foreign tourists, and its value ranges from 3.2 to 4.3 (although it may be higher). This means that greater multiplier effects mean greater absorption power of the market in which certain goods and services are placed, of tourist and non-tourist character. Globally, multiplier effects do not create a direct increase in national income, because it is not a matter of movement, but of income spillover. In that sense, tourism has a significant advantage over the classic export of goods, which flows abroad to the produced social wealth (Vujović, 2007, pp. 215-229).

Economic results of the tourist turnover at high degree are reflected in the development of agriculture and agribusiness, transport, trade, manufacturing and service industry. The development of production and services in transport industry results from the increase in demand and turnover which can be achieved through tourism and catering. Economic effects and development in general economy are increasing through tourism consumption.

Tourism is incorporated directly into three out of four (extractive industry, agriculture, processing/manufacturing industry, and 
transport) basic fields of material production-transport, processing/manufacturing industry, and agriculture. Apart from the extractive industry, agriculture and processing/manufacturing industry, there is also the fourth field of material production which also transcends various stages, craft, manufacturing, and mechanical work - the transport industry (Locomotion industry) whether it transports people or goods. According to the above-quoted claim, it can be said that tourism is the first (or one) of the five basic fields of material production. Since there are multiple direct connections between tourism and transport, agriculture and processing/manufacturing industry and if we exclude the extractive industry, then tourism is one of the four basic fields of material production. Developed tourism countries can, due to revenues received from tourism, compensate the necessary goods of extractive industry, thus tourism can be treated as the first of the four basic fields of material production (tourism, agriculture, transport and processing/ manufacturing industry). It is precisely these four fields of material production that make up the basis and upgrade of further economic development (Premović, Arsić, Vujović, 2012, p. 582).

Based on the analysis of the systematic exchange of tourism and other industries, it can be concluded that each of them is an integral part of the total tourism product, as shown in the following input-output table.

\begin{tabular}{||c|l||}
\hline INPUT-OUTPUT & \multicolumn{1}{c|}{ TOURISM } \\
\hline AGRICULTURE & $\begin{array}{l}\text { - agricultural products for food preparation; } \\
\text { - unproductive spaces for building tourist capacities, tourist infrastruc- } \\
\text { ture and supra structures; } \\
\text { - decorative plants and arrangements for decorating tourist facilities } \\
\text { and entire tourist recipes and } \\
\text { - surplus workforce. }\end{array}$ \\
\hline INDUSTRY & $\begin{array}{l}\text { - products for construction and equipping of tourist capacities of infra- } \\
\text { structure and supra structure; } \\
\text { - products of mass consumption, both for direct and non-board service; } \\
\text { - excess of available investment funds for the development of tourism, } \\
\text { as consumers and industrial products and } \\
\text { - methods and equipment of tourist products. }\end{array}$ \\
\hline \hline
\end{tabular}

TABLE 1: CROSS-SECTORAL RELATIONS BETWEEN TOURISM AND OTHER INDUSTRIES ${ }^{\text {A }}$ 


\begin{tabular}{|c|c|}
\hline TRADE & $\begin{array}{l}\text { - consumer goods for non-boarding needs of tourists; } \\
\text { - supply of tourist shopping centers (handicrafts, handicrafts, souve- } \\
\text { nirs, etc.); } \\
\text { - replenishment of the fund of free time on vacation and } \\
\text { - exchange of staff and financial resources, as a motivation for overall } \\
\text { tourism development. }\end{array}$ \\
\hline TRAFFIC & $\begin{array}{l}\text { - traffic terminals (airports, ports, marinas, railway and bus stations, } \\
\text { parking spaces, garages, etc.); } \\
\text { - means of transport; } \\
\text { - indirect modernization of tourism and shortening of travel time and } \\
\text { - constant growth in the number of passengers, ie tourist. }\end{array}$ \\
\hline CONSTRUCTION & $\begin{array}{l}\text { - complete construction operation; } \\
\text { - investments; } \\
\text { - rapid construction of tourist capacities and } \\
\text { - continuous modernization of building styles, use of natural materials, } \\
\text { various chemical agents that do not negatively affect tourist facilities. }\end{array}$ \\
\hline TOURISM & $\begin{array}{l}\text { - constant growth of tourist volume, structure and quality; } \\
\text { - diversification of the tourist market; } \\
\text { - opening new destinations and new regions and } \\
\text { - constant increase of income, employment, exchange of goods and pas- } \\
\text { sengers, understanding between nations, etc. }\end{array}$ \\
\hline CATERING & $\begin{array}{l}\text { - expanding the tourist offer in the basic facilities for accommodation } \\
\text { and nutrition of tourists; } \\
\text { - quantitative and qualitative growth of non-board consumption; } \\
\text { - presentation of ethno-gastronomic and other characteristics of the } \\
\text { people in the destination, country or wider macro-region and } \\
\text { - overall development of tourism through various capital investments, } \\
\text { employment of the local population, use of destination products, etc. }\end{array}$ \\
\hline CRAFTS & $\begin{array}{l}\text { - production craft enables maintenance and constant functioning of } \\
\text { tourist facilities of infrastructure and suprastructure, as well as produc- } \\
\text { tion of necessary craft items for permanent use; } \\
\text { - service trades with the production of consumer goods, especially in } \\
\text { the non-board part of tourism; } \\
\text { - home-made products, souvenirs, ethno products, etc. i } \\
\text { - fitting into the total tourist product, ie. development without delay. }\end{array}$ \\
\hline
\end{tabular}

TABLE 1: CROSS-SECTORAL RELATIONS BETWEEN TOURISM AND OTHER INDUSTRIES ${ }^{\text {A }}$ 


\begin{tabular}{||l|l||}
\hline & - cleaning of tourist centers and implementation of environmental re- \\
& quirements; \\
- all information on available services that help the safety, health and & general stability of tourists; \\
COMMUNAL & - permanent presence of parking services, in order to protect the envi- \\
ACTIVITIES & $\begin{array}{l}\text { ronment, but also in order not to waste time on the arrival and accom- } \\
\text { modation of tourists and }\end{array}$ \\
& $\begin{array}{l}\text { - taking care of arranging the tourist place, but also of all tourist corri- } \\
\text { dors, changing the landscape architecture and creating the experience } \\
\text { of a well-organized recipe. }\end{array}$ \\
\hline \hline
\end{tabular}

TABLE 1: CROSS-SECTORAL RELATIONS BETWEEN TOURISM AND OTHER INDUSTRIES ${ }^{\text {A }}$

a Milenković, S. (2009). Tourism and Economy, [monograph], University of Kragujevac - Faculty of Economics Kragujevac, pp. 95-96.

Tourism acts on entities and factors that exist in a particular tourist destination including its population, employees, investors, that is, affects the prosperity of all companies that meet the needs of tourists, but also the increase in the number of jobs made, the increase in the mass of goods and services produced within a certain period, which stimulates the socio-economic and economic development of the tourist destination.

As a labor-intensive economic activity, tourism generates job creation "due to the fact that catering and travel agencies require through their work technology increasing the number of employees in relation to other economic activities" (Stefanović, Urošević, 2012, p. 76.). It is particularly important to accentuate the important role of tourism in facilitating greater employment of the younger population, bearing in mind that the number of young people employed in the tourism sector is almost twice the number of young people working in some other economic or non-economic sector. Tourism are human resource intensive activity, employing directly and indirectly $8 \%$ of the global workforce. According to the UNWTO, it is estimated that one job in the core tourism industry creates about one and a half additional or indirect jobs in the tourism-oriented economy.

The World Economic Crisis of 2008 and its impact on tourism $^{4}$ The collapse of the US financial market of high-risk mortgage housing loans was the main cause of the emergence and rapid expansion of financial crisis in 2008. The enormous overestimation of real estate triggered the emergence of the financial crisis that soon 
expanded to the real sector, causing the global economic crisis that impacted every country in the world, leading to a sharp fall of the basic macroeconomic aggregates, above all the GDP, international trade, balance of payments and employment.

The main generator of the emergence of the financial crisis was the expansive monetary policy that was conducted in the period from 2002 to 2006 and the deregulated financial market. After the collapse of the US mortgage market, investors withdrew their funds from the world stock exchanges and invested them in national debt securities. Due to the globally reduced demand and increased inflation, the slowdown in global economic growth began in 2008. In developed economies, consumer prices recorded growth of $3,5 \%$ in 2008 , compared to $2,1 \%$ in 2007 . All these phenomena caused the global economic growth rate by the end of 2008 to be $3,4 \%$, while the growth rate in 2007 amounted to 5,2\%.

The three key consequences of the global crisis are illiquidity, a decline in the GDP that caused a general recession and, consequently, a steady decline in the unemployment rate.

According to the data on year-over-year fluctuations in real GDP, US and European economies entered a recession in the fourth quarter of $2008(-0,8 \%$ and $-1,4 \%$, respectively) which continued and deepened in 2009, while in 2010 real growth in GDP was registered in both the US and EU. In the same period (2008 and 2009) there was an increase in the unemployment rate in the most developed regions, and the unemployment rate in the US increased from 5,8\% in 2008 , to $9,5 \%$ in June 2009 , while the unemployment rate increased from $7,6 \%$ in 2008 to the recorded 8,9\% in June 2009. Further intensifying of the crisis was stopped by the associated stimulus measures of monetary and fiscal policy and financial regulative measures undertaken by governments of developed countries. The stimulus measures undertaken at the end of 2008 and in 2009 contributed to lessening the consequences of the global crisis, particularly halting a deeper decline of economic activity.

The current economic and financial crisis had a reflection in the tourism sector as well. As a result of the decline in GDP and unemployment rate on the global level in 2008 and 2009, tourism turnover also declined. Namely, the increase in tourist arrivals in the

4 Premović, J., Arsić, Lj. (2018). Tourism as an important factor of economic development of the Western Balkans countries, Western Balkans Economies in EU Integration - Past, Present and Future, CEMAFI International Association, ISBN 979-10-96557-18-9, Nica, 2018, pp. 92-106. 
first four months of 2008 was $5 \%$ higher than in 2007 , but as a result of the acceleration of global crisis in the second and third quarters of 2008 that increase was significantly reduced. The negative growth tendencies in international tourism that occurred during the second half of 2008 were intensified in 2009 , so $8 \%$ less tourist arrivals were registered in the first four months of 2009, compared to the same period in 2008. A total of 247 million tourist arrivals were made in the world, compared to the same period in 2008, when it was 269 million (Table 2).

\begin{tabular}{|c|c|c|c|c|c|c|c|c|c|c|}
\hline & \multicolumn{4}{|c|}{$\begin{array}{l}\text { INTERNATIONAL TOURISM } \\
\text { REVENUE (IN BILLIONS) }\end{array}$} & \multicolumn{3}{|c|}{$\begin{array}{c}\text { FLUCTUATIONS OF } \\
\text { CURRENT PRICES (IN \%) }\end{array}$} & \multicolumn{3}{|c|}{$\begin{array}{c}\text { FLUCTUATIONS OF } \\
\text { PERMANENT PRICES } \\
(\text { IN } \%)\end{array}$} \\
\hline & 2005 & 2007 & 2008 & $2009^{*}$ & $07 / 06$ & $08 / 07$ & $09^{*} / 08$ & $07 / 06$ & $08 / 07$ & $09 * / 08$ \\
\hline CURRENCY & & & & & 9.1 & 6.3 & -4.1 & 5.5 & 1.3 & -5.7 \\
\hline$\$$ & 679 & 858 & 941 & 852 & 15.3 & 9.7 & -9.4 & 12.1 & 5.7 & -9.1 \\
\hline$€$ & 545 & 626 & 640 & 611 & 5.7 & 2.2 & -4.5 & 3.5 & -1.0 & -4 \\
\hline
\end{tabular}

TABLE 2: OVERVIEW OF RECEIVED REVENUES IN TOURISM IN THE PERIOD FROM 2005 TO $2009^{\mathrm{A}}$

a UNWTO. (2010). Tourism Highlights, 2010 Edition, p. 4.

In 2009, all the leading tourist regions registered negative results, except Africa which registered growth of 3\%. Europe, as a macro-tourism destination ended 2009 with a total decrease in tourism values of as much as 6\%, while the Middle East and America registered a $5 \%$ decline. Asia and Pacific had great turbulence in 2009. In the first six months of 2009 (from January to June) there was a 7\% increase; in the second half of the year, this increase was reduced to $4 \%$, so at the end of 2009 Asia and Pacific had a total decrease of $2 \%$ (UNWTO, 2010, p. 4). However, in spite of all economic problems and disturbances, tourism already achieved real increase in number of tourists of $4,6 \%$ and the increase in revenue of $3,9 \%$ compared to the previous 2010, as shown in Tables 3 and 4. 


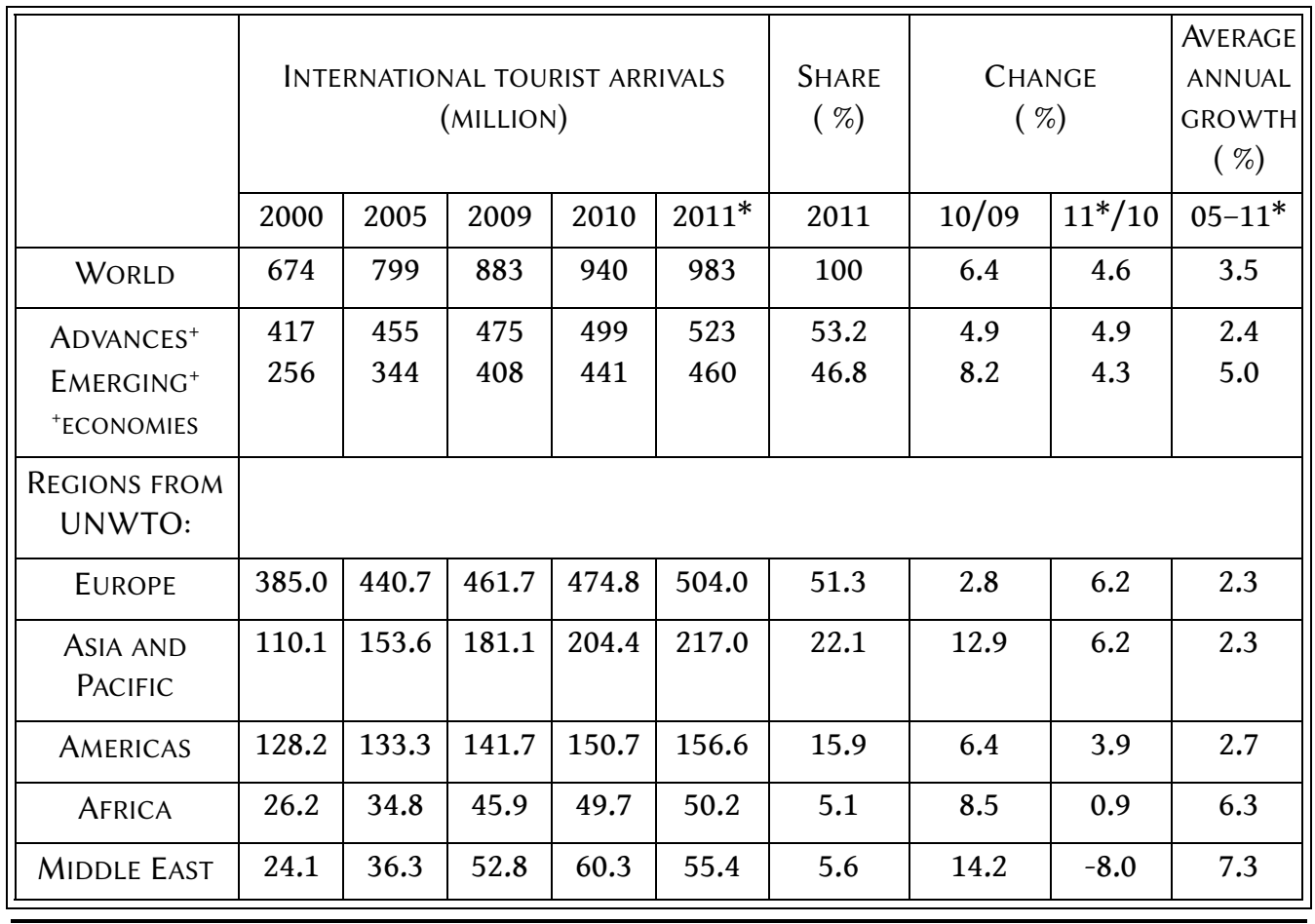

TABLE 3: OVERVIEW OF INTERNATIONAL TOURIST ARRIVALS FROM 2000 TO $2011^{\mathrm{A}}$

a Adopted from: UNWTO. (2012). Tourism Highlights, 2012 Edition, p. 4.

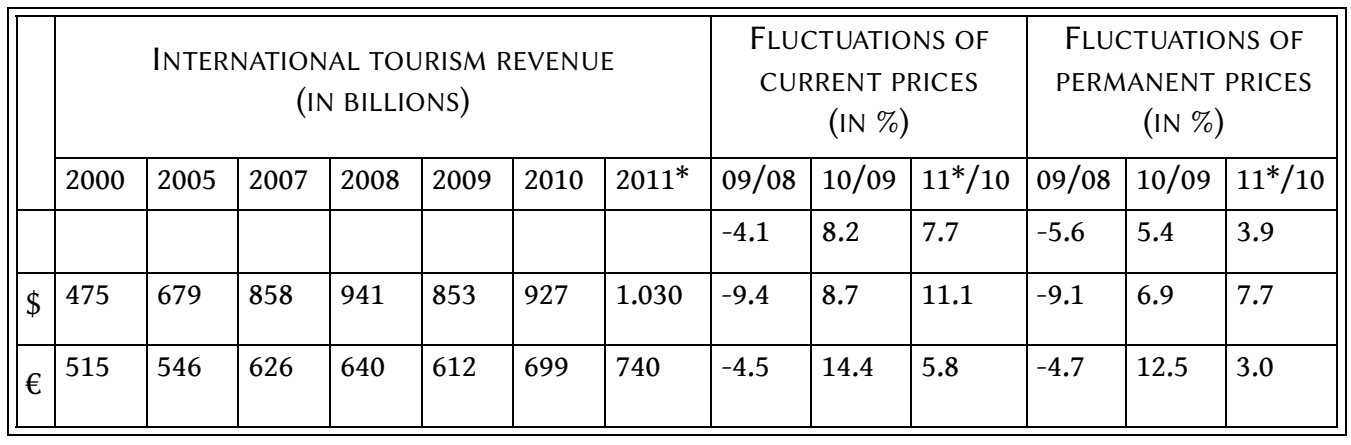

TABLE 4: OVERVIEW OF INTERNATIONAL TOURISM RECEIPTS FROM 2000 TO $2011^{\mathrm{A}}$

a Adopted from: UNWTO. (2012). Tourism Highlights, 2012 Edition, p. 4.

Official data of the World Tourism Organization on the results of the tourism industry achieved in 2011(of 983 million tourists that 
contributed to generating a total of 1,042 million \$ which represents a real increase in number of tourists of $4,6 \%$ and the increase of revenues by $3,9 \%$ compared to 2010 ), show the development performances of tourism and its role in overcoming the current global economic and financial crisis.

International tourist arrivals exceeded the figure of 1 billion for the first time in 2012, out of which the number of foreign tourists increased by 40 million, from 995 million in 2011 to 1,035 billion in 2012. Asia and Pacific achieved the highest growth of 7\%, Africa had a growth of $6 \%$ and America was at $5 \%$ in tourist arrivals. In the same period, international arrivals in Europe, as a leading tourist destination, increased by $3 \%$, although Central Europe continues to fall by $5 \%$.

In 2012, there was a registered increase of $4 \%$ in tourist arrivals and in generated revenues from international tourism. The revenue received from the international tourism in 2012 amounted to 1,075 billion $\$$, compared to the 1,042 billion $\$$ generated in the previous year. After the "magical" figure of 1 billion ( 1,075 billion) received from international arrivals in 2012, this growth was continued in the following years, as shown in the following charts (Table 5).

\begin{tabular}{|c|c|c|c|c|c|c|c|c|c|c|c|c|c|}
\hline & \multicolumn{7}{|c|}{$\begin{array}{l}\text { INTERNATIONAL TOURISM REVENUE } \\
\text { (IN BILLIONS) }\end{array}$} & \multicolumn{3}{|c|}{$\begin{array}{c}\text { FLUCTUATIONS OF } \\
\text { CURRENT PRICES } \\
(\text { IN } \%)\end{array}$} & \multicolumn{3}{|c|}{$\begin{array}{c}\text { FLUCTUATIONS OF } \\
\text { PERMANENT PRICES } \\
(\text { IN } \%)\end{array}$} \\
\hline & 2005 & 2007 & 2008 & 2009 & 2010 & 2011 & $2012^{*}$ & $10 / 09$ & $11 / 10$ & $12 / 11$ & $10 / 09$ & $11 / 10$ & $12 / 11$ \\
\hline & & & & & & & & 8.2 & 8.7 & 7.1 & 5.5 & 4.7 & 4.0 \\
\hline$\$$ & 679 & 858 & 941 & 852 & 930 & 1.042 & 1.075 & 8.7 & 12.0 & 3.1 & 7.0 & 8.6 & 1.0 \\
\hline$€$ & 545 & 626 & 640 & 611 & 702 & 749 & 837 & 14.4 & 6.7 & 11.7 & 12.6 & 3.9 & 9.0 \\
\hline
\end{tabular}

TABLE 5: OVERVIEW OF INTERNATIONAL TOURISM RECEIPTS FROM 2005 TO $2012^{\text {A }}$

a Adopted from: UNWTO. (2013). Tourism Highlights, 2013 Edition, p. 6.

After international tourist arrivals reached the "magic" figure of 1 billion (1.035 billion) for the first time in 2012, this growth continued in the following years, as shown in the following tables (Tables 6 and 7). 
SOCIO-ECONOMIC AsPectS OF TOURISM IN THE MODERn SOCIETY

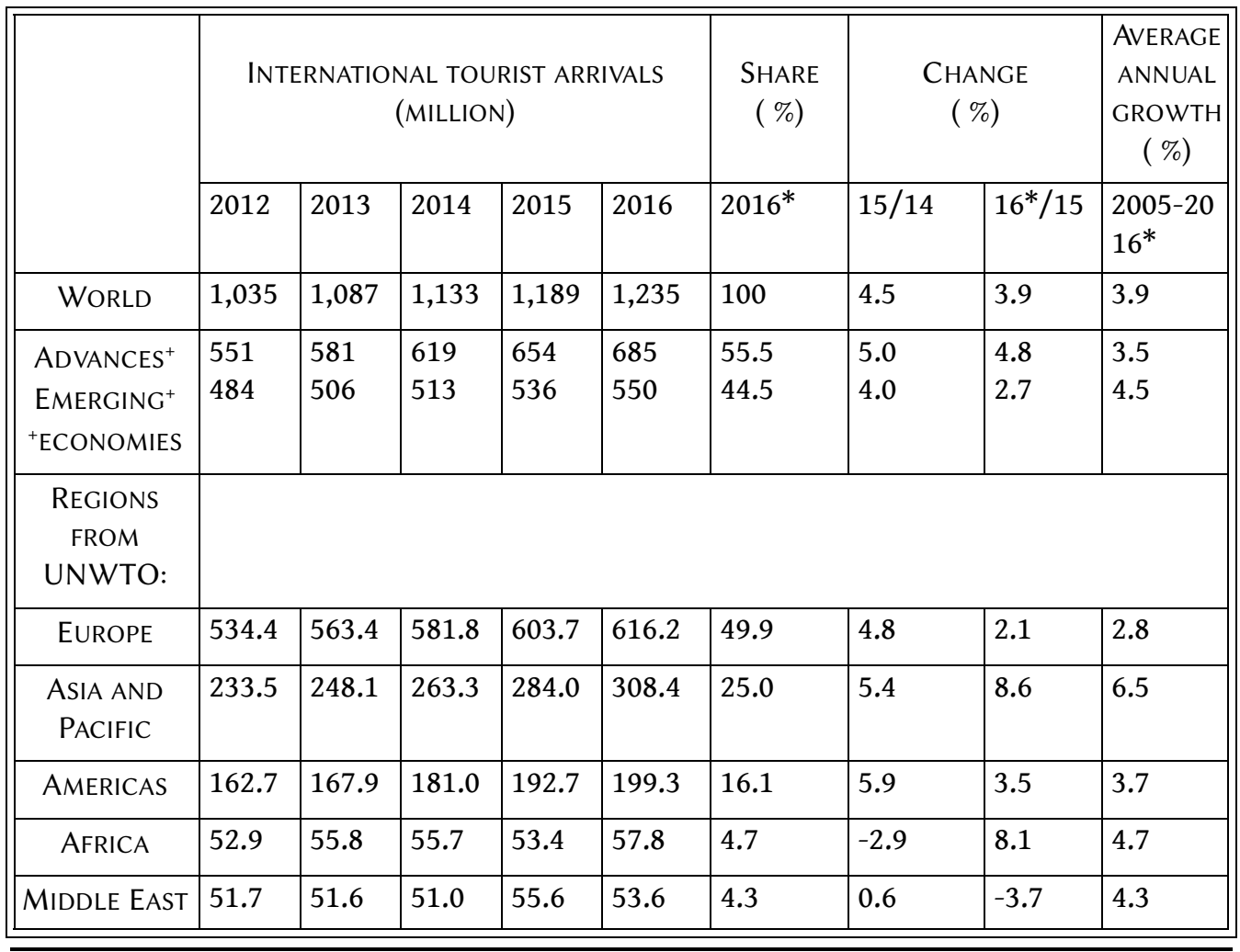

TABLE 6: OVERVIEW OF INTERNATIONAL TOURIST ARRIVALS FROM 2012 TO $2016 .{ }^{\mathrm{A}}$

a Adopted according to: UNWTO. (2014). Tourism Highlights, 2014 Edition, p. 4.; UNWTO. (2015). Tourism Highlights, 2015 Edition, p 4; UNWTO. (2016). Tourism Highlights, 2016 Edition, p. 4., UNWTO. (2017). Tourism Highlights, 2017 Edition, p. 6.

\begin{tabular}{|c|c|c|c|c|c|c|c|c|c|c|c|c|c|}
\hline & \multicolumn{7}{|c|}{$\begin{array}{l}\text { INTERNATIONAL TOURISM REVENUE } \\
\text { (IN BILLIONS) }\end{array}$} & \multicolumn{3}{|c|}{$\begin{array}{c}\text { FLUCTUATIONS OF } \\
\text { CURRENT PRICES } \\
(\text { IN } \%)\end{array}$} & \multicolumn{3}{|c|}{$\begin{array}{c}\text { FLUCTUATIONS OF } \\
\text { PERMANENT PRICES } \\
(\text { IN } \%)\end{array}$} \\
\hline & 2010 & 2011 & 2012 & 2013 & 2014 & 2015 & $2016^{*}$ & $\begin{array}{l}14 / \\
13\end{array}$ & \begin{tabular}{|l|}
$15 /$ \\
14
\end{tabular} & \begin{tabular}{|l|}
$16^{*} /$ \\
15
\end{tabular} & $\begin{array}{l}14 / \\
13\end{array}$ & $\begin{array}{l}15 / \\
14\end{array}$ & $\begin{array}{l}16^{*} / \\
15\end{array}$ \\
\hline & 100 & 105 & 109 & 115 & 120 & 125 & 128 & 6.4 & 5.1 & 4.0 & 4.3 & 4.1 & 2.6 \\
\hline$\$$ & 961 & 1,073 & 1,110 & 1,197 & 1,252 & 1,196 & 1,220 & 4.6 & -4.5 & 2.0 & 2.9 & -4.6 & 0.7 \\
\hline$€$ & 725 & 771 & 864 & 901 & 942 & 1,078 & 1,102 & 4.5 & 14.4 & 2.2 & 4.1 & 14.3 & 2.0 \\
\hline
\end{tabular}

TABLE 7: OVERVIEW OF INTERNATIONAL TOURISM RECEIPTS FROM 2012 TO $2016 .^{\mathrm{A}}$ 
a Adopted according to: UNWTO. (2017). Tourism Highlights, 2017 Edition, p. 6.

Based on the latest data published by the World Tourism Organization in the annual report for 2019 called International Tourism Highlights 2019 , a total of 1.401 billion tourist arrivals were realized in 2018, which represents a nominal growth of 72 million compared to the previous 2017. year, or an increase of 5.4\%. In the same period, revenue growth of $4.4 \%$ was achieved, since in 2018 , revenue of 1.451 billion dollars ( 1.299 billion euros) was collected from performing tourist activities. In 2017, this revenue amounted to 1.346 billion dollars, or 1.192 billion euros.

\begin{tabular}{|c|c|c|c|c|c|c|c|}
\hline & \multicolumn{3}{|c|}{$\begin{array}{l}\text { INTERNATIONAL TOURIST } \\
\text { ARRIVALS } \\
(\text { MILLION })\end{array}$} & \multirow{2}{*}{$\begin{array}{c}\text { SHARE } \\
(\%) \\
2018^{*}\end{array}$} & \multicolumn{2}{|c|}{$\begin{array}{l}\text { CHANGE } \\
(\%)\end{array}$} & \multirow{2}{*}{$\begin{array}{c}\text { AVERAGE } \\
\text { ANNUAL } \\
\text { GROWTH } \\
(\%) \\
2010-2018^{*}\end{array}$} \\
\hline & 2010 & 2017 & $2018^{*}$ & & $17 / 16$ & $18 * / 17$ & \\
\hline WORLD & 952 & 1,329 & 1,401 & 100 & 7.0 & 5.4 & 5.0 \\
\hline $\begin{array}{l}\text { ADVANCES }^{+} \\
\text {EMERGING }^{+} \\
{ }^{+} \text {ECONOMIES }\end{array}$ & $\begin{array}{l}515 \\
437\end{array}$ & $\begin{array}{l}730 \\
598\end{array}$ & $\begin{array}{l}762 \\
639\end{array}$ & $\begin{array}{l}54.4 \\
45.6\end{array}$ & $\begin{array}{l}6.3 \\
7.9\end{array}$ & $\begin{array}{l}4.3 \\
6.8\end{array}$ & $\begin{array}{l}5.0 \\
4.9\end{array}$ \\
\hline \multicolumn{8}{|l|}{$\begin{array}{c}\text { REGIONS FROM } \\
\text { UNWTO: }\end{array}$} \\
\hline EUROPE & 486.4 & 673.3 & 710.0 & 50.7 & 8.6 & 5.5 & 4.8 \\
\hline $\begin{array}{l}\text { ASIA AND } \\
\text { PACIFIC }\end{array}$ & 208.2 & 324.0 & 347.7 & 24.8 & 5.7 & 7.3 & 6.6 \\
\hline AMERICAS & 150.4 & 210.8 & 215.7 & 15.4 & 4.7 & 2.3 & 4.6 \\
\hline AFRICA & 50.4 & 62.7 & 67.1 & 4.8 & 8.5 & 7.0 & 3.6 \\
\hline MIDDLE EAST & 56.1 & 57.7 & 60.5 & 4.3 & 4.1 & 4.7 & 0.9 \\
\hline
\end{tabular}

TABLE 8: CURRENT DATA OF TOURIST ACTIVITY IN THE WORLD MARKET - TOURIST ARRIVALS FROM 2010 TO 2018. ${ }^{\mathrm{A}}$

a Adopted according to: UNWTO. (2019). Tourism Highlights, 2019 Edition, p. 5.

Europe still ranks first with a share of $48 \%$, followed by Asia and the Pacific with $25.6 \%$ and America with a share of $16.8 \%$ in the total number of realized tourist trips. Africa and the Middle East achieved significantly lower shares with $3.2 \%$ and $2.9 \%$, respectively. 
The analysis of the history of tourism indicates that, in economics as a science, there is an uncompromising attitude that free time and free financial funds, as the final goals of all economic activities, are a prerequisite for the development of tourism. The expansion of tourism has had a positive impact on the economic and financial factors, primarily on the growth of the employment rate, not only in tourism, but also in other economic and noneconomic activities from agriculture, transport, and construction to telecommunications and the like. Modern tourism includes an increasing number of new destinations, which is why it is one of the main factors of international trade and a source of employment and income for a large number of countries.

Organizations and individuals responsible for planning and development, apart from economic and to some extent geographical ones, did not pay enough attention, especially in the early stages of tourism development to other, increasingly important aspects and principles of tourism. First of all, ecological, ethnosocial, cultural and especially safety aspects and principles have been significantly neglected. In addition to those, the safety aspects of tourism in recent decades require more and more attention. The forms and ways of manifesting negative influences and serious destructive phenomena in tourism or through the development of tourism are numerous. Today, the process of globalization-the rapid movement of people, capital, goods and services on the planetary leveland accelerated technical and technological development, in addition to a number of positive effects, allow faster flow of serious destructive phenomena such as terrorism.

When it comes to the development of tourism, the practice has confirmed that terrorist activities occur and act most often in two directions: towards the natural environment (environmental terrorism) and towards the social community (cultural and ethnosocial terrorism). Destructions towards the natural environment can occur through various forms of pollution, physical changes in the landscape of the area and physical destruction of the entire ecosystems. The complete destruction of certain ecosystems or certain animal and plant species is certainly ecological terrorism.

The effect of terrorist activities directed at the social community is manifested through the physical destruction of property and persons, which is faced by larger tourist places and destinations. It should be noted that extensive tourism development, in addition to serious security problems, brings other negative phenomena, such 
as prostitution, money laundering, drug trafficking, various epidemics, arms trafficking, alcoholism, various thefts and robberies, fights, etc. If the performance of tourist activity is viewed from the global, geopolitical aspect, it is necessary to notice, as Professor Slavoljub Vujović (2018) points out, that today in the new division of forces and definition of centers of power on the planetary level, great powers exercise their 'soft power' through tourism.

Observed from the socio-cultural aspect on a global level, tourism as a mass social phenomenon significantly affects the reduction and even erasure of numerous prejudices, above all linguistic, cultural, religious, national, class. Tourism has a positive effect on all articipants, both on those who participate in the creation of a specific tourist service, and on the users of these services, i.e. tourists. Tourism broadens the cognitive horizons of all participants in tourism, which is one of the key positive aspects of tourism. Getting to know new cultures and getting to know other people, with their customs, traditions, religion, habits, represents a significant positive social impact of tourism. This group of positive influences certainly includes the acquisition of new knowledge and the expansion of knowledge about these new spaces, religions, customs and cultures. Tourism also has a positive effect on increasing the degree of tolerance, understanding and acceptance of diversity of all kinds.

At the same time, with the expansion of the cognitive horizon, the tourism industry develops awareness of the importance of preserving nature and the environment by preserving the authenticity of natural, cultural and anthropogenic heritage at the local, micro and macro levels. Acquiring new knowledge and insights into the importance of applying the basic principles of sustainable development in order to ensure sustainable tourism development is also of increasing importance and relevance.

On the other hand, and/or at the same time, tourism can cause certain negative sociocultural consequences. Namely, the massification of tourism and tourist globalization can lead to completely opposite effects, such as the feeling of fear of the masses and of an unknown space, religion, culture, customs, traditions; further development of existing prejudices towards a certain group of tourists; increasing conflicts and the inability to overcome them; losing the specificity of the local environment and local tradition and accepting the negative achievements of modern living: drugs, alcohol, prostitution, etc; uncontrolled and unadapted develop- 
ment of local space due to mass tourism by destruction of natural and anthropogenic local resources and other.

Tourism is therefore a complex activity that can contribute to positive socio-economic and cultural development, but at the same time, inadequate and uncontrolled management of a tourist destination can have negative socio-cultural, but also economic consequences. Above all, these negative impacts of mass tourism are reflected in the degradation of nature and the environment, the loss of local identity through the disruption of cultural heritage and natural and anthropogenic resources, and local biodiversity.

However, despite the negative phenomena and processes on the international sociopolitical and economic scene, tourism is becoming the most promising economic activity today, as this study shows. "Despite all these dangerous challenges that today's civilization brings with it in this area, tourism is once again taking a big step and thus taking up more and more space and turning it into a tourist attraction, which brings profit. Therefore, it is no coincidence that tourism is developing at a rapid pace and permanently brings innovations, which are often sufficient if they successfully survive for one or two seasons" (Božović, 2009, p. 52).

This statement is supported by the fact that the tourist activity has been growing steadily since the middle of the 20th century, and that in 2017, thanks to the number of 1.329 billion tourists in 2017, it took third place for the first time, just behind the chemical and the oil industry and it overtook the auto industry. This growing trend continued in 2018, in which a record number of 1.401 billion tourists influenced the realization of the total tourist turnover of as much as 1.700 billion dollars.

REFERENCES Božović, R. (2009). Kultura turizma, Sociološka luča, III/1.

Boselman, F. P. (1983). Jedan vid omladinskog turizma u Amsterdamu. Kultura, br. 60-61.

Čomić, Đ. (1990). Psihologija turizma. Beograd: Turistička štampa.

Elaković, S. (2006). Sociologija slobodnog vremena i turizma (Fragmenti kritike svakodnevlja), treće izdanje, Centar za izdavačku delatnost Ekonomskog fakulteta u Beogradu, Beograd.

Encensberger, H. M. (1983). Jedna teorija turizma, časopis Kultura, broj 6061, Beograd.

Gligorijević, Ž., Stefanović, V. (2012). Turizam kao društveno-ekonomski fenomen: pojavni i vremenski obuhvat. Ekonomske teme, 3/2012, 269-282. 
Hese, H. (2002). Umetnost dokolice, Alfa, Beograd.

Jandrešić, V. (2001). Turizam u interdisciplinarnoj teoriji i primjeni - Zbornik istraživanja. Zagreb: Školska knjiga.

Jović, B. (1983). Organizacija kulturnih delatnosti u turizmu, časopis Kultura, broj 60-61, Beograd.

Milenković, S. (2009). Turizam i ekonomija. Kragujevac: Ekonomski fakultet.

Nikić, S. (2012). Sociologija turizma i održivi turizam. Tivat: Fakultet za mediteranske poslovne studije.

Premović, J., Jovanović, D., Arsić, Lj. (2015). The role of tourism in fostering rural development, Sixth International Scientific Symposium „Agrosym 2015“, Book of Proceedings, 1949-1954, October 15-18, 2015, Jahorina.

Premović, J. (2016). Characteristics of human resources in Serbian rural tourism, Economics of Agriculture 2/2016. EP 2016, (63) 2 pp. 633-647.

Premović, J., Arsić, Lj., Vujović, S. (2012). Globalni strategijsko-razvojni aspekti turizma. Zbornik radova XIII Majske konferencije o strategijskom menadžmentu MKSM2012, 580-587. Bor.

Premović, J., Arsić, Lj. (2018). Tourism as an important factor of economic development of the Western Balkans countries. Western Balkans Economies in EU Integration - Past, Present and Future. Nica: CEMAFI International Association.

Vujović, S. (2007). Agroturizam u funkciji razvoja privrede Vojvodine, Ekonomika poljoprivrede, vol. LIV, broj 2, str. 215-229, Beograd.

Vujović, S., Macura, R., Spajić, J. (2011). Razvojni aspekti turizma (opština Knić), Ekonomika poljoprivrede, vol. 58, specijalni broj 1/2011, god./vol. LVIII, SB/SI-1 (1-368), 41-47, Beograd.

Vujović, S., Cvijanović, D., Štetić, S. (2012). Destinacijski koncept razvoja turizma, monografija, Institut za ekonomiku poljoprivrede, Beograd.

Vujović, S., Spajić, J., Vukosavljević, D. (2011). Anatomiziranje turističke tražnje u svetlu ekonomskih zakonitosti, fenomena, efekata i paradoksa $u$ potrošnji, Ekonomika poljoprivrede vol. 58, broj 4/2011, 563-575, Beograd.

Vujović, S. (2018). Turizam u svijetlu ekonomije, monografija, Ekonomski institut Beograd.

Vujović, S., Premović, J., Macura, R. (2019). Turistička destinacija u funkciji nosioca turističke ponude, Međunarodna konferencija: Mediji i ekonimija, Zbornik radova, str. 198-205, DOI:10.7251/BLCZB0219198V, 20. septembar 2019, „Banja Luka COLLEGE“, Banja Luka.

Vukadinović, P., Premović, J., Đokić, N. (2018). Intangible values of culture in the function of tourist offers, International May Conference on Strategic management- IMCSM18, ISSN 2620-0597, Volume XIV, Issue (2) (2018), ISBN 978-86-6305-082-2, pp. 67-75, Maj 25-27, 2018, Bor, Serbia. 
Vukićević, S. (2007). Menadžment slobodnog vremena u turizmu, CID, Podgorica.

SOURCES World Tourism Organization (UNWTO), Data as collected by UNWTO, August 2010. UNWTO (2010). Tourism Highlights, 2010 Edition.

World Tourism Organization (UNWTO), Data as collected by UNWTO, UNWTO (2013). Tourism Highlights, 2013 Edition.

World Tourism Organization (UNWTO), Data as collected by UNWTO, UNWTO (2014). Tourism Highlights, 2014 Edition.

World Tourism Organization (UNWTO), Data as collected by UNWTO, UNWTO (2015). Tourism Highlights, 2015 Edition.

World Tourism Organization (UNWTO), Data as collected by UNWTO, UNWTO (2016). Tourism Highlights, 2016 Edition.

World Tourism Organization (UNWTO), Data as collected by UNWTO, UNWTO (2017). Tourism Highlights, 2017 Edition.

World Tourism Organization (UNWTO), Data as collected by UNWTO, UNWTO (2018). Tourism Highlights, 2018 Edition.

World Tourism Organization (UNWTO), Data as collected by UNWTO, UNWTO (2019). Tourism Highlights, 2019 Edition.

ЈЕЛЕНА Ђ. ПРЕМОВИЋ

ЕКОНОМСКИ ИНСТИТУТ БЕОГРАД

ЉИљАНА Ј. АРСИЋ

УНИВЕРЗИТЕТ У ПРИШТИНИ СА ПРИВРЕМЕНИМ СЕДИШТЕМ

У КОСОВСКОЈ МИТРОВИЦИ, ЕКОНОМСКИ ФАКУЛТЕТ

САЖЕТАК

\section{ДРУШТВЕНО-ЕКОНОМСКИ АСПЕКТИ ТУРИЗМА \\ У САВРЕМЕНОМ ДРУШТВУ}

Специфичност туристичког тржишта и повезаност савремених туристичких производа са бројним привредним и ванпривредним делатностима условљава вишеструкост друштвено-економских ефеката туризма.

Развојем туризма се стварају могућности за покретање низа других делатности, што значи да туризам представља значајан фактор за покретање укупног привредног и економског развоја. Нарочито важну улогу туризам има у укупном друштвено-економском развоју недовољно развијених земаља и региона. Туризам може допринети позитивном друштвено-економском ра- 
звоју, али истовремено, неадекватно и неконтролисано управљање туристичком дестинацијом, може условити низ негативних социолошко-културолошких, али и економских последица.

У раду се истражују основни социолошко-културолошки и економски аспекти и утицаји туризма. Аутори посебну пажњу посвећују анализи мултипликативних ефеката туризма на развој одређене дестинације. Полазећи од историје појаве путовања и туризма као делатности, кључних мотива и друштвено-економских ефеката, анализирана је Светска економска криза из 2008. године, њен настанак, узроци и последице деловања на целокупну светску привреду и економију, посебно на туристичку делатност, након чега су анализирани актуелни економски показатељи туристичке делатности у светској привреди и пројекције очекиваних трендова.

У овом раду, у фокусу анализе се налазе туристичка путовања и економски и социолошко-културолошки аспекти деловања туристичке делатности на туристичку дестинацију, појединца и друштво у целини.

КљУчнЕ РЕчи: путовања; туризам; потребе; мотивације; друштвено-економски утицаји.

Овај чланак је објављен и дистрибуира се под лиценцом Creative Commons Ауторство-Некомерцијално Међународна 4.0 (СC BY-NC 4.0 |

https://creativecommons.org/licenses/by-nc/4.0/).

This paper is published and distributed under the terms and conditions of the Creative Commons Attribution-NonCommercial International 4.0 licence (CC BY-NC 4.0 | https://creativecommons.org/licenses/by-nc/4.0/). 